\title{
INFLUENCE OF DRUM CHIPPER SETTING ON THE WOOD CHIPS PERFORMANCE
}

\author{
Ismail, Z. E.* M. I. Ghazy**
}

\begin{abstract}
Recently, spread in the world many different categories of wood chipper to be convert the field trees waste to chips. In Egypt, especially in the new land farms the wastes of field trees represent an immense problem. For this reason, the wood chipper machine manufactured in small workshops scattered in the region of Dakahlia governorate. Because of the owners of these workshops, do not have experience in the design of wood chipper machines. Therefore, it immediately needed to evaluate each of the chipper design and its operation. Therefore, the aim of recent paper are to evaluate the design of offset slider crank for drum wood chipper and to evaluate operating parameter of drum chipper on wood chip removal rate (WCRR, $\left.m^{3} / h\right)$, actual chip thickness (ACT), share plan angle (SPA), chip thickness ratio (CTR), chip reduction coefficient (CRC), size classification of wood chips (SCC) and the machine productivity. The operating parameters of the local chipper machine (model MUPM) included two wood sit positions in chipper (perpendicular of wood fiber relative to cutting drum (Per) and parallel to wood fiber $(P)$; two cutting drum revolution (Per $1=5000 \mathrm{rpm}$ and $P e r 2=5500 \mathrm{rpm})$ two types of wood (white wood or exported and local wood or feedstock) and two moisture content (17\% for white wood and $33 \%$ for feedstock).
\end{abstract}

Key words: chipper machine- wood chips- cutting angle- chip thicknesssize classification of wood chips

\section{INTRODUCTION}

I n Egypt, there are no clear statistics or documented data on the volume of waste field trees or green waste, but in recent times it represents a real problem. On the other hand and at the local level, increased demand for the utilization wood chip as good bed for the animals bedding or use as source of renewable energy. Consequently, it led to increase the requests on wood chipper equipments.

\footnotetext{
* Prof. of Power Technology and Machinery, Agric. Eng. Dept., fac. of Agric., Mansoura Univ., Egypt.

** Literature of Agric. Eng., Agric. Eng. Dept., fac. of Agric., Mansoura Univ., Egypt.
} 
Generally, there are several types of chipping machines relative to the cutting principles currently in use. Mainly are; disc chipper, twin disc chipper, v-drum hop chipper, v-drum, hog chipper and cylinder drum chipper. On the other hand, Toenshoff and Denkena (2013) reported that, depending on the work-piece material and the cutting conditions, the following mechanisms of chip formation can be distinguished as continuous, lamellar, segmented and discontinuous chips formation (figure 1). Different methods of cutting have been employed in the wood products industry depending on the use of the wood and purpose of operation (Sutherland and DeVor -1986). In all of these cutting methods, the quality of surface obtained because of the process affected by factors related to the processed material (tree species, quality and moisture contents of materials, etc.). Operating parameters such as different angles affect the wood chip removal rate. The clearance angle controls the pulling of the logs towards the chipper plate (Uhmeier-1995), and consequently, the chip size distribution. The clearance angle also affects the resulting chip thickness rate (Zmitrowicz-2006). The knife angle used is normally between $30^{\circ}$ and $37^{\circ}$. Kajberg and Wikman (2007) and Bergander and Salmén (2000) showed that a decrease in the knife angle from $40^{\circ}$ to $30^{\circ}$ reduces the chip thickness, the cutting force and chip damage.

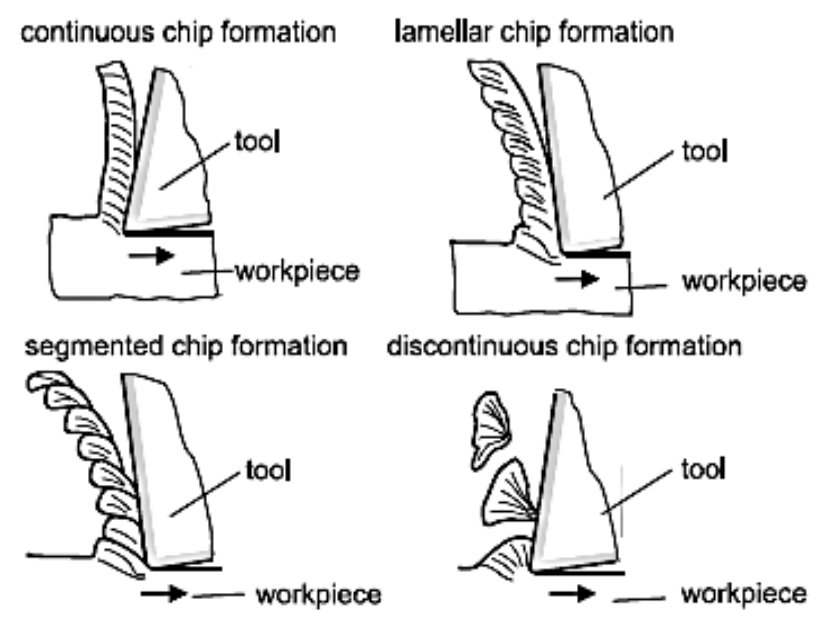

Fig. (1) Mechanisms of chip formation (Author, Bergander and Salmén -2000) 
Jernkvist and Thuvander (2001) identified that there are at least two chip formation processes i.e. an opening mode and a forward shear mode. The $20^{\circ}$ and $30^{\circ} \mathrm{knife}$ angle produced chips by opening. The $40^{\circ} \mathrm{knife}$ angle formed chips by forward shearing in a small percentage of cases and the $50^{\circ}$ knife angle formed chips by forward shearing in most instances. The performance of a cutting tool or the machine ability of a work material can be evaluated by measuring the chip reduction coefficient. There is difference in the chip reduction coefficient for parallel, and perpendicular to the fiber axis. Several models have been simulated to study parameters/factors that influence the chip reduction coefficient [Gonçalves and Néri (2005); Wen-Hsiang Lai (2000); Tlusty (1991) and Kline et al. (1982)]. These parameters include; number of cutter knife, cutting angle, bluntness of cutters, etc. and other factors related to; the machinery technological level, feeding rate, cutting speed, etc. (Toenshoff and Denkena-2013).

The common construction of wood chipper machines that can produce wood chips are; the cone-screw wood chipper and the drum or the disc chippers. Operators stated that disc chippers produce more uniform chips than drum chippers, especially if fed with good quality raw material. In contrast, flexible small branches may pass through the disc slots uncomminuted, resulting in low chip quality. For this reason, operators believe that drum chippers are the best when dealing with small-size feedstock, such as tops and branches (Svensson-2007). Therefore, many attempts were carried out to improve the drum chipper. One of them, is investigated offset slider mechanism which the power supply to drum chipper almost, directly though bully and flywheel and on other design indirectly by slider mechanism (Ismail-2004).

The offset slider mechanism is constructed by the Egyptian workshop owners and because of the owners of workshop have low experience about the design of such machine and these machine also facing some problems when you running in the domestic market. Therefore, it requires re-evaluating of such equipment design. Consequently, the aim of recent paper are to evaluate the design of offset slider crank for drum wood 
chipper theoretically and practically, to evaluate operating parameters of drum chipper on wood chip removal rate (SRR), chip thickness ratio (CTR), chip reduction coefficient (CRC), size classification of wood chips (SCC) and the machine productivity.

\section{MATERIAL AND METHODS}

\section{Wood chipper machine}

The common construction of wood chipper machine was constructed in small worship at Dahlia governorate and was re-design at worship of agricultural engineering-Mansoura University. The general via of wood chipper machine local model MUPM as shown in Fig. (2), consists of two principal parts. The first is power supply unit that including the offset slider mechanism, hoop, flywheel, chains and belts.

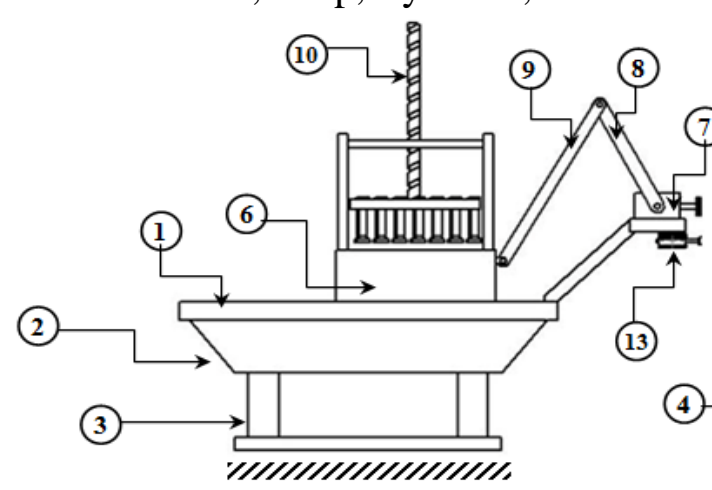

ELEV

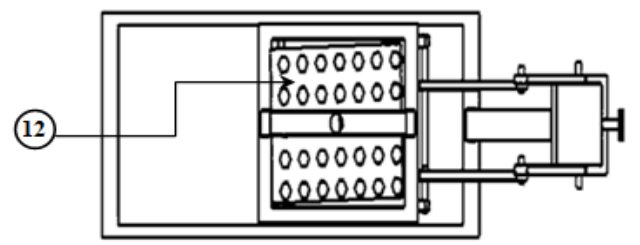

Plan
1- Frame

6- Slider wood box
2- Chips container

7-Worm gear 8- Connected rod 9-Coubler

10- Vertical spinner shaft 11-Sliding guide

13- Offset slider mechanism motor

Figure (2): Layout of investigated offset slider chipper machine

The second is the chipper unit, that containing drum, slider box of wood and chips container. The two units were established on the main frame 
with dimensions of $1900 \times 800 \times 900 \mathrm{~mm}$ length, width and height respectively. It made from iron with $U$ section of $75 \times 75 \times 3 \mathrm{~mm}$. Four iron legs with $U$ section of $100 \times 100 \times 5 \mathrm{~mm}$ were welded with the lower surface of the container that storing the chips output from a process operation of the chipper. The basic dimensions of offset slider mechanism after modification are illustrated in Fig. 3. It driven with electrical motor of $7.0 \mathrm{~kW}$ with $2990 \mathrm{rpm}$. The motor motion travel to two crank arm of offset slider mechanism by worm gear with reduction of 1:7. At rotating the crank arm, the motion conveying to the cobbler that bolted with slider box.

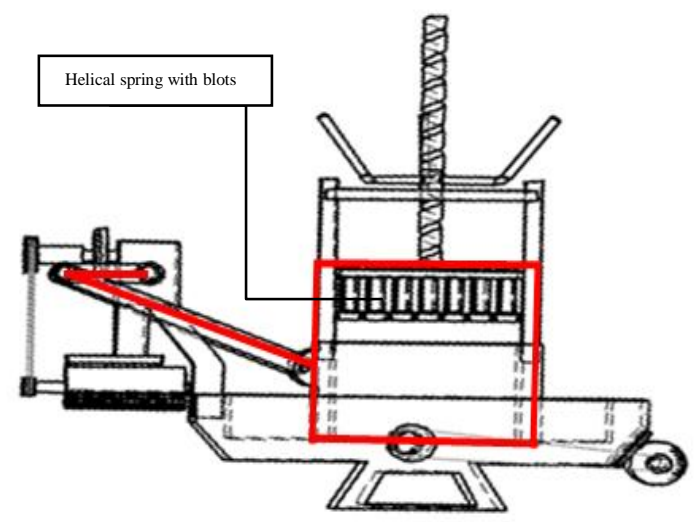

Figure (3): Offset slider mechanism and slide box specification

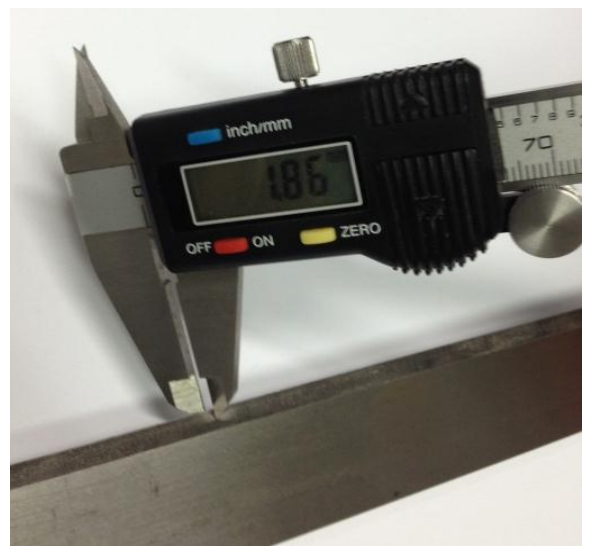

Figure (4): Share of chipper drum

The principal part of second unit is chipper drum. It is made of a closed drum equipped with blades, as long as the whole drum axis, a counterblade and an interchangeable output-sieving grid for chips calibration. The closed drum made from steel iron with diameter of $100 \mathrm{~mm}$ and 800 $\mathrm{mm}$ length. It fixed by two-roller thrust bearing on the main frame under the surface of slider box and near from the end side of it. A longitudinal gab on the drum surface is constructed and inside the gab, the sharp share thickness shown in figure 4 is constant and equal $1.86 \mathrm{~mm}$.

The drum of chipper connected with transmutation system that takes the rotation from electrical motor with $5.5 \mathrm{~kW}$ and $1440 \mathrm{rpm}$. The slide box dimension is $800 \times 700 \times 500 \mathrm{~mm}$ long, width and height. It was from iron 
sheet with $5 \mathrm{~mm}$ thickness. To reduce the friction forces and keep the slider box motion easy it laying on two-rood bar. The top surface of slider box covered with rectangle plate with $10 \mathrm{~mm}$ thickens. This plate moving up and down through the four guides by spinner and nut (handedly system). Numbers of helical spring with guides were distributed on the lower surface of plate to keep the force between the woods and chipper drum constant (figure 3).

\section{Experimental condition}

Two major of studies are identified. Theoretically, to determine the dimensions of offset slider mechanism and re-designed it to avoid the machine disadvantages like supplementary vibration and high noise. Practically, the indoor experiment conducted to evaluate the now designed.

\section{Theoretical consideration}

It is including two shares. One relative to offset slider-crank motion and the other relative to the drum share operation.

\section{The fundamental operating theory offset slider-crank motion}

Referring to the mechanism system that transmit the motion from the center of worm gears (in put motion) to the slide chips box (out let motion) as shown in figure (3), it easy to see that, the motion is movement sliding by four-bar system and take the form of offset slider crank. From principles basic, this style of movement able to conform the chipper stroke in times bigger than that return stroke. In addition, by referring to the basic guideline principles of the machines theory to achieve this requirement must be:

- Recall that an offset slider-crank has quick return action.

- Must determine the required Q (Time ratio) and $\beta$ (Imbalance angle) where time ratio equal time of advance stroke per time of return stroke.

- To produce smooth acceleration must be L3(coupler length) > L2 (crank length)

- Coupler ratio equal (coupler length (L3) / crank length (L2)) and must be $>4$. Then the coupler length must be more than that fourth times of crank length and in normal case may be equal 6 crank time 
Regarding to the dimension of offset slider crank for machine chipper before modified, the input link $2\left(\mathrm{~L}_{2}\right)$ is rotating at a constant angular velocity with length of $350 \mathrm{~mm}$, the offset distance $\left(\mathrm{L}_{1}\right)$ is $360 \mathrm{~mm}$ and coupler length (L3) of $1120 \mathrm{~mm}$. Then, the angle of crank ( $\theta 1)$, when the slider is at the left-most position is equal to 152.13 degree (calculated according to David -2012 and regarding to figure 5). In addition, the crank angle $(\theta 2)$ when the slider is at the right-most position $=345.82$ degree. Then, represents the stroke length is $744.5 \mathrm{~mm}$ and the time ratio is 1.16 .

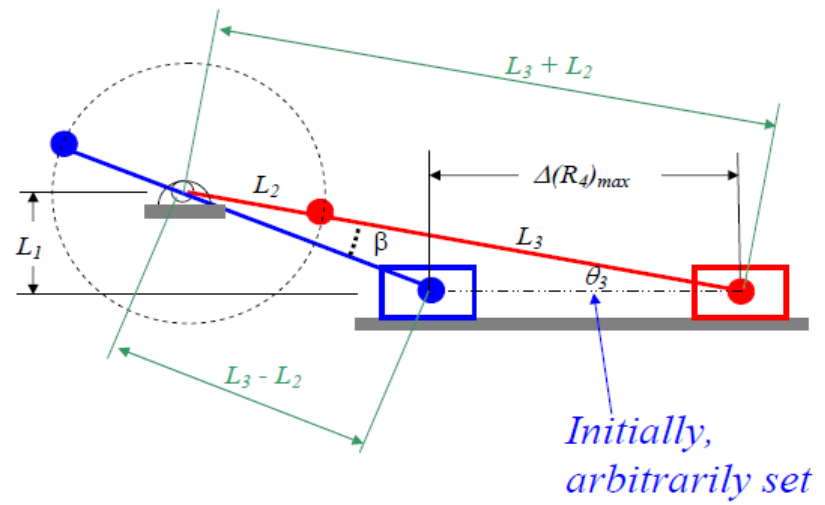

Figure (5): Offset slider-crank mechanism

Also, the displacement respect to time in seconds for the slider unit (container of supply wood to drum chipper) as shown in figure (6) indicates some imperfection such as: the time ratio is very low, the stability of machine is very little and the velocity and acceleration diagram is unharmonious.

So, it's investigated a simple program to determine the optimum dimension to over com above deficiency. From the investigated program, the dimension of offset slider crank for machine chipper are L1 $=400$ $\mathrm{mm} ; \mathrm{L} 2=250 \mathrm{~mm}$ and $\mathrm{L} 3=1120 \mathrm{~mm}$, then the $\theta 1=148.24$ degree; $\theta 2=$ 344.21 degree and the time ratio $=1.95$. The relationship between time and each of displacement, velocity and acceleration diagrams illustrates in figure (7). From diagrams in figure, the motion of slide crank is very state and homogenous relation. 

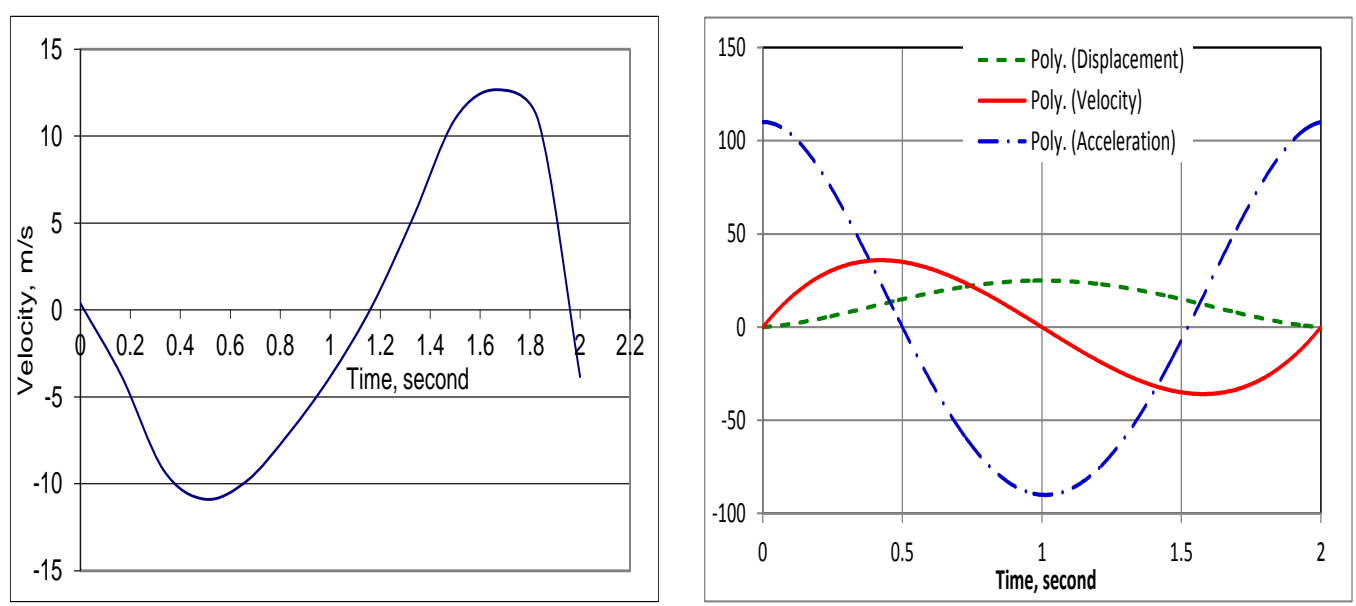

Figure (6): Displacement diagrams for Figure (7): Displacement velocity and the slider before modified acceleration diagrams after modified

\section{Drum-Share operation}

Concerning to the simulation work of wood chip machine, that obtainable in the Department of Agricultural Engineering after modified, the cutting device unit of wood is subject to the system of orthogonal cutting model (OCM). As shown in figure (8), the share tool is inclined with rake angle ( $\alpha=$ shear rack angle) and cutting angle ( $\varphi=$ shear plane angle).

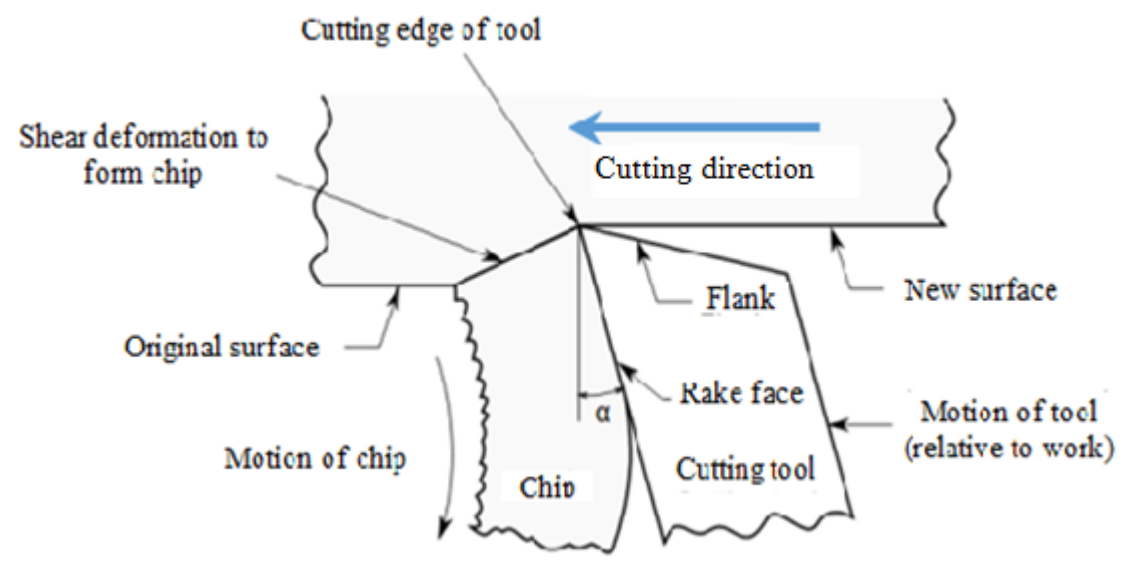

Figure (8): The orthogonal cutting system rack $(\alpha)$ angles

The chip plan angle $(\varphi)$ was identified as $" \tan \varphi=\mathrm{r} \cos \alpha /(1-\sin \alpha) "$ sited from David (2012). Where; $(\alpha)$ is share rake angle, and (r) is the 
chip thickness ratio (CTR). The identification of CTR is the relation between " $t_{0}$ " (thickness of the chip prior) to " $t_{c}$ " (chip thickness after separation) as $C T R=t_{o} / t_{c}$. From the primary experiments allows notes that $\left(\mathrm{t}_{\mathrm{c}}\right)$ chip thickness after cut is always greater than before, so chip ratio is always less than 1.0. This result comes to an agreement with Kajberg and Wikman (2007) and Thuvander, et al. (2000).

\section{The indoor experiment conditions}

The tests were conducted in March 2015 at the wood feedstock that scattered from Mansoura University Garden and the residual from wood workshop. The wood chipper machine alternately fed with two different feedstock types: white wood residual (imported) and garden wood residual (feedstock- local). All feedstock were fresh and came in pieces with an approximate length of $70 \mathrm{~cm}$. The average moisture content ranged in-between 20 and $46 \%$ for local wood (feedstock) and for the imported of below 20\%. The feedstock were chosen because they are widely available and often easy used for chip production.

The moisture content for two woods under experiment were quickly recorded using a $\mathrm{J}$-Lite wood moisture content. It recognized worldwide as the most accurate method for measuring moisture with moisture range from 6 to 30\%. It built-in calibration checks with $9 \mathrm{~V}$ battery as shown in figure (9).

The main chips dimensions (thickness, wide and length) were measured by taking as samples from each repetition for all variables under experiments and using electrical caliper model 16 ES with accuracy of $0.01 \mathrm{~mm}$ (figure-4).

Wood chips removal rate under all variables were evaluated by weighing all wood chips produced within each repetition per unit time.

Particle size distribution, according to European Standard CEN/TS 15149-1 four sieves were used to separate the following chip classes: $>20 \mathrm{~mm}, 20-50$ $\mathrm{mm}, 50-100 \mathrm{~mm}$. Each fraction was then weighed with a precision scale (figure-10). 


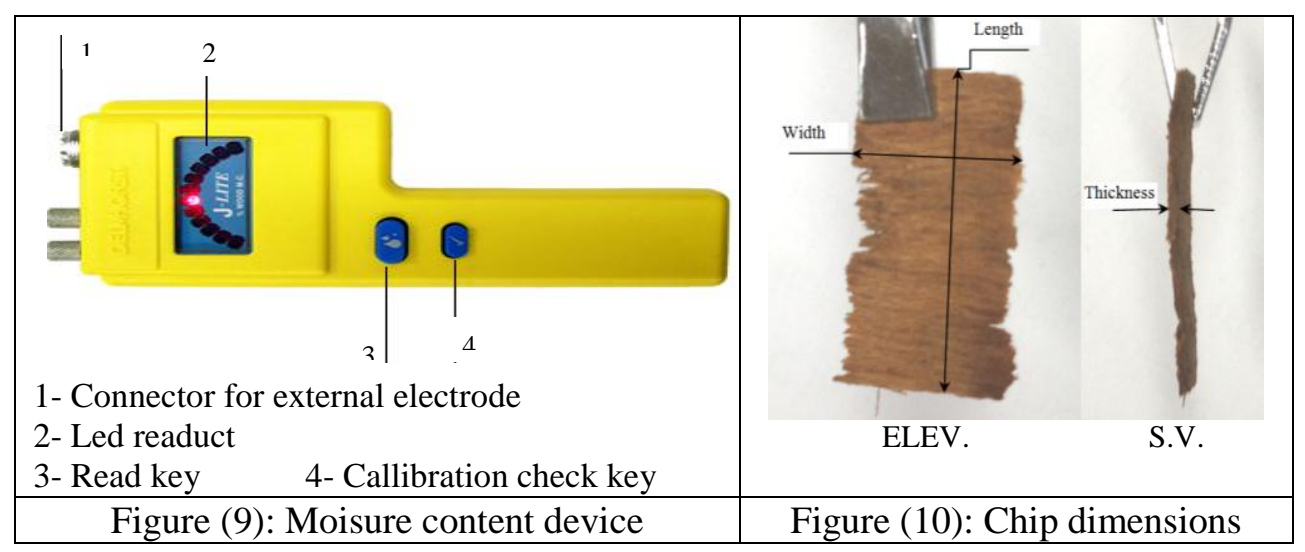

Data were analyzed with the Excel statistics software. In particular, the software was used for performing a typical analysis of variance (ANOVA), especially suited to the factorial experiment just described. Analysis of variance was conducted to determine the most parameters affecting chips variation. In addition, the relationship between productivity, piece size and tree part was estimated using multiple linear regression technique.

\section{RESULTS AND DISCUSSION}

Wood chips removal rate (WCRR, $\mathrm{m}^{3} / \mathrm{h}$ )

The relationship between the cutting depth of drum knife and the amount of wood chips removal rate (WCRR) illustrated in figure (11) under different cutting drum revolution (5000; 5500 and 6000 rpm). Generally, the above relationship was found as directly proportional function. It mean that increasing the cutting depth increased the WCRR, but the rate of increasing is higher for $6000 \mathrm{rpm}$ drum revolution by about of 1.2 than at $5000 \mathrm{rpm}$ under cutting depth of $2 \mathrm{~mm}$. However, there were 1.25 and 1.42 times at 3.0 and $4.0 \mathrm{~mm}$ share cutting depth. This is due to the wood specifications on experimentation is not matching. Under the specification required for product wood chips with thickness of $2 \mathrm{~mm}$, then the amount of chips removal rate were $1.08 ; 1.13$ and $1.30 \mathrm{~m}^{3} / \mathrm{h}$ at cutting speed of 5000; 5500 and 6000 rpm respectively.

\section{Actual chips thickness}

The setting angle of share knife is the major parameters affecting the actual chips thickness (Ismail -2009). Figure (12-A) shows the 
relationship between share setting angle and the actual wood chips thickness. The above figure indicated that at increasing the share-setting angle from 20 to 30 degree, the actual chips thickness increased. For example at 20;22; 26 and 30 degrees of share setting angle, the average of chips thickness recorded $0.16 ; 0.19 ; 0.22$ and $0.28 \mathrm{~mm}$ respectively.

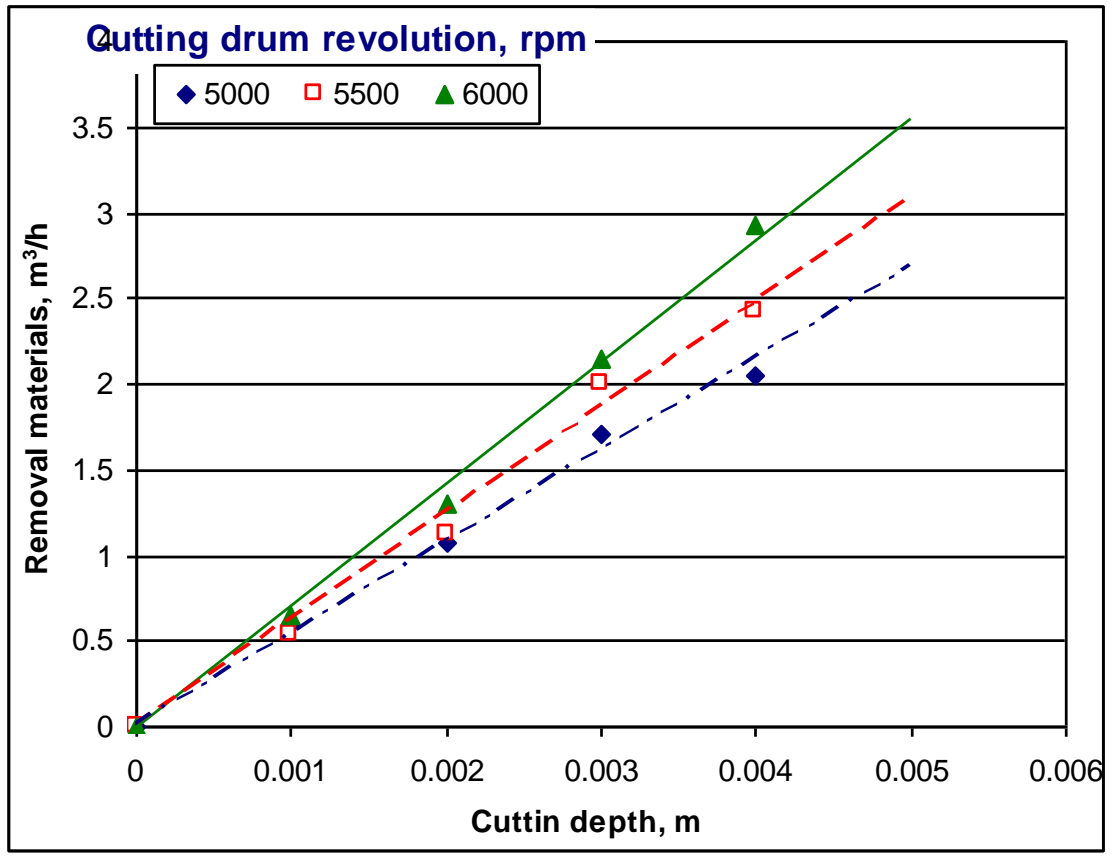

Figure (11): The cutting drum speed versus amount of chip removal rate

\section{Share plan angle (degree)}

The analysis was conducted to determine the effect of share plan angle on the chips thickness. The results of above relation illustrates in figure (12B). Generally, by ascending share plan angle descending the chips thickness this results agreement with Ismail and Abou Habaga (2008). To regulate the cutting share with the share plan angles needed to flow this steps; for example at $0.2 \mathrm{~mm}$ chips thickness will be found at seating angle of 23 degree and 50 degree share plan angle.

\section{Chips thickness ratio (CTR)}

Because of the major factors affecting power consumption of drum chipper machine is the values of cutting force which is depending of the cutting depth that consider as function on wood chips thickness not chips 
length or width. Then the wood thickness consider as the main parameters which the study identification. The relation between cutting depth and the actual chips thickness is consider the chips thickness ratio (CRT). Figure (13) illustrates the relationship between the actual chips thickness and the CTR at different share setting angle. Generally, from figure the results related that the CTR is direct preoperational with each of chips thickness and setting angle.

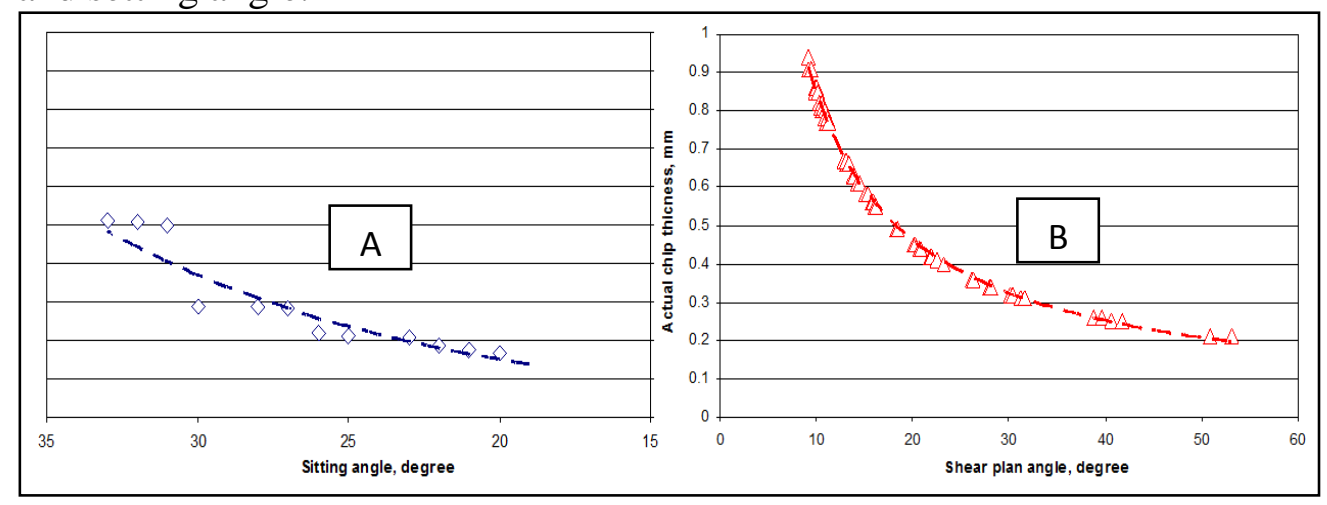

Figure (12): Actual chips thickness as function for sitting angle and share plan angle

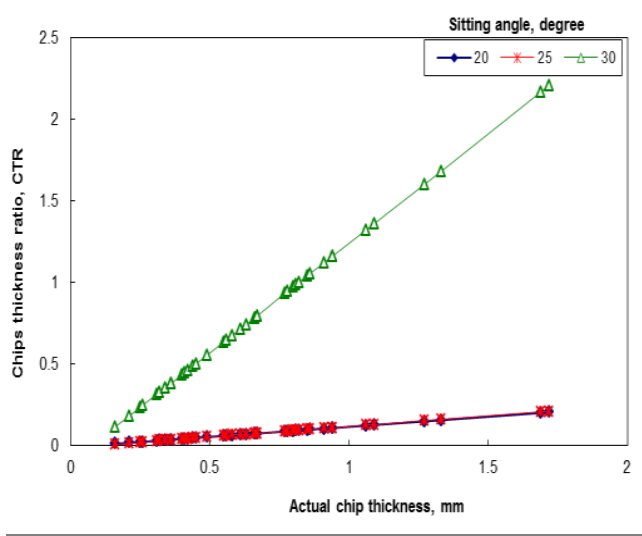

Figure (13): The relationship between the actual chips thickness and the CTR

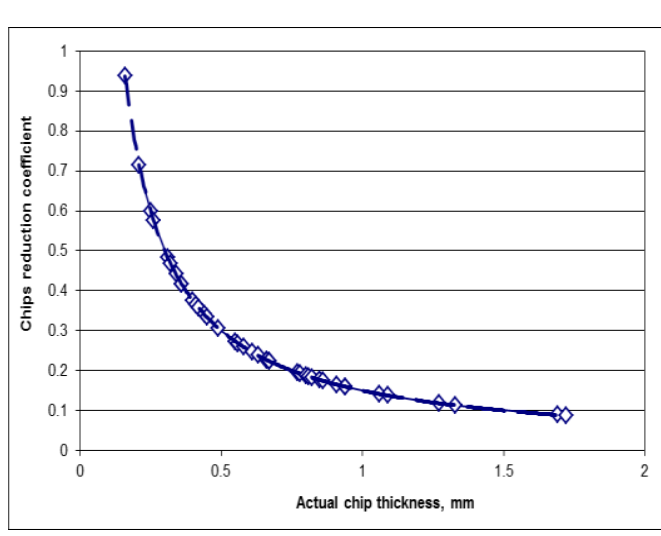

Figure (14): The actual chips thickness via the CRC

\section{Chip reduction coefficient (CRC)}

Figure (14) conducts the function of actual chips thickness and the chip reduction coefficient. The above relation is inversely functioning. By increasing the actual chips thickness the CRC decreased for all treatment under study and it non-significant different. The same trend was found for 
the relationship between the share-setting angle (StA) and chap reduction coefficient (CRC). At actual chips thickness range from 0.25 to 0.5 the CRC is rabidly decreased and it very slowly decreased at chips thickness more than $0.5 \mathrm{~mm}$.

\section{Size classification of wood chips}

The second part of experiment is evaluate the product of machine by identifies the size classification of wood chips (SCC). It evaluates under two wood sit positions in chipper-box (perpendicular of wood fiber relative to cutting drum (Per) and parallel to wood fiber (P); two cutting drum revolution $($ Per1 $=5000 \mathrm{rpm}$ and Per2 $=5500 \mathrm{rpm}$ ) two types of wood (white wood or exported and local wood or feedstock) and two moisture content (17\% for white wood and $33 \%$ for local wood). Three methods were conducted to evaluate SCC as show in figure (15). From figure and by hand touch, it easy to notes that, the photos " 1 " and " 2 " is more softly than that for " 3 " and " 4 " and vice versa for " 5 "; " 6 "; "7" and "8". Also, the smallest chips pieces found at variables in photo"2". Furthermore, the largest wood chips dimensions were found over the sieves with much of $10 \mathrm{~mm}$ at variables in photo 5 than that in variables at photos "6"; "7" and "8".

\section{The frequency functions}

The frequency of main dimension (thickness - width - length) for wood chips under different variable illustrates in figure (16). Mostly, the above relationship in frequency curves represents the right side of the normal distribution curve except at variables of local wood moisture content of $17 \%$, the cutting wood perpendicular on wood fiber and at measuring the thickness and width for wood chips.

Frequently, from figure, the peak frequency for wood chips thickness, width and length recorded at fields of (1-6mm); (3-14mm) and (3-33mm) respectively for white wood. However, there were $(0-3.5 \mathrm{~mm}) ;(1-6 \mathrm{~mm})$ and $(3-20 \mathrm{~mm})$ respectively for tree woods. It means that the chips dimension for white woods is height than that for tree woods. 


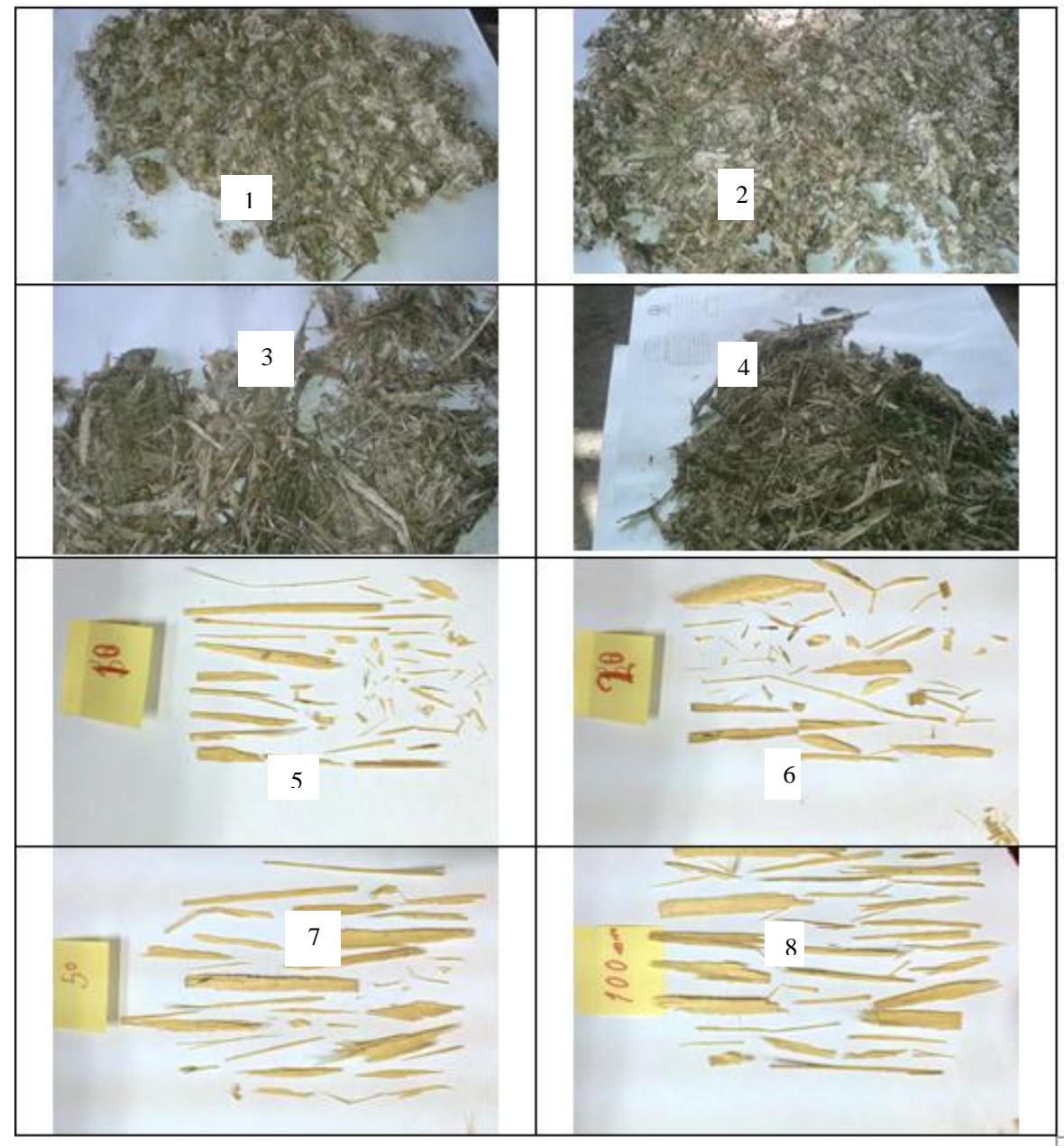

1- L.W , M1, Par1,V1 2- L. W M1Par2,V2

3-1. W M1, P. V1 4-L.W M1, P, V2

5- Ex.W , M2, Par1,V1 6- Ex. W M2Par2,V2

7-Ex. W M2, P. V1 8-Ex.W M2, P, V2

Figure (15): The photographic of chip out from chipper machine

On the other hand, at measuring chips width parameter and under P; Per1 and Per2 variables, there are not differences effects. At middle category 6 $\mathrm{mm}$ the frequency recorded $20 \% ; 19.355 \%$ and $12.5 \%$ respectively for white woods. But, there were $40 \% ; 44 \%$ and $45 \%$ for tree wood and at middle category of $1.25 \mathrm{~mm}$. Referring to chips length, there were highest different between P; Per1 and Per2 variables. In addition, there were highest differences between white and tree woods. The Per2 parameter recorded the best frequency with the lowest category range. 
White woods (imported)

Tree woods (local)
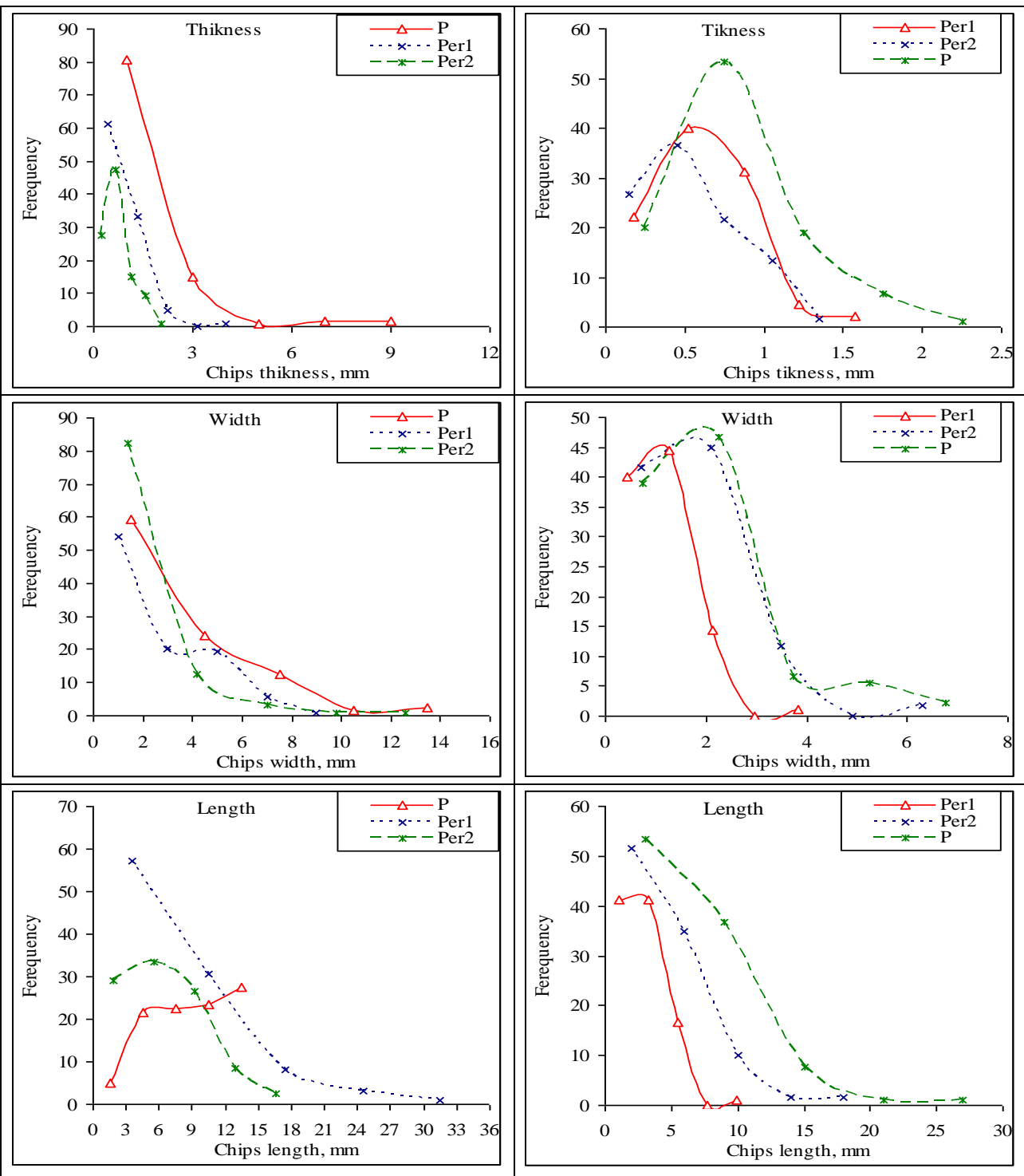

Figure (16): The frequency curves for wood chips distribution

\section{Average chips dimension}

Figure (17) indicated the average chips dimension over the sieves under different variables (P; Per1 and Per2) for two woods types. From figure, clarify the amount of average chips dimension (Th; W and L) increased for sieves with mesh of 20,50 and $100 \mathrm{~mm}$ for white wood but for local wood the above relation is gradually increased. 
White woods (imported)

Tree woods (local)

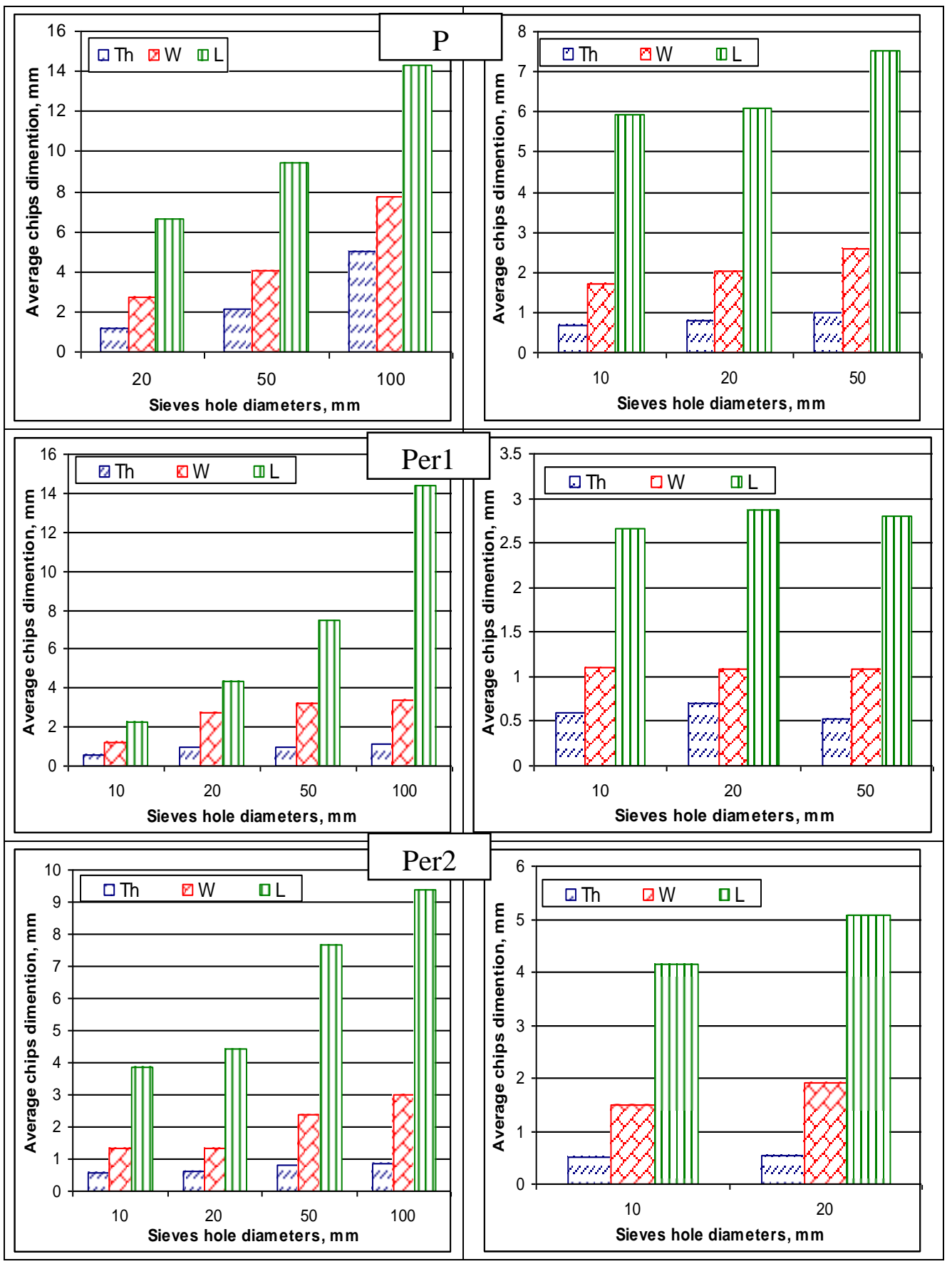

Figure (17): Average chips dimension curves for wood chips variables 
The average chips thickness (Th) recorded $1.15 ; 2.15$ and $5.05 \mathrm{~mm}$ at mesh of 20,50 and $100 \mathrm{~mm}$ respectively for white wood and "P" variables against $0.6 ; 0.7$ and $0.5 \mathrm{~mm}$ for local woods and under the same variables. The best results were found at Per2 for local wood that "Th" recorded $(0.5$ and $0.54 \mathrm{~mm})$ and "W" verified $(1.49$ and $1.90 \mathrm{~mm})$ and "L" noted $(4.2$ and $5.08 \mathrm{~mm})$ at sieves with mesh of $20,50 \mathrm{~mm}$ respectively. Table (1) represents the stander deviation of chip dimension above the sieves under different variables (P; Per1 and Per2) for two woods types. The variation of SD is very low and nearly equal (from 0.321 to 5.880) for local wood under all treatment. However, for white wood is wide deviation from 0.29 to17.81.

Table (1): The stander deviation for average chips dimension

\begin{tabular}{|c|c|c|c|c|c|c|c|}
\hline \multirow{2}{*}{ 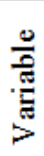 } & \multirow{2}{*}{$\begin{array}{c}\text { Sieves } \\
\text { diameter, } \\
\mathrm{mm}\end{array}$} & \multicolumn{3}{|c|}{ White } & \multicolumn{3}{|c|}{ Local } \\
\hline & & Per1 & Per2 & $P$ & Per1 & Per2 & $P$ \\
\hline \multirow{4}{*}{ 崫 } & 10 & 1.706 & 0.296 & ----. & 0.321 & 0.272 & 0.252 \\
\hline & 20 & 3.503 & 0.430 & 0.370 & 0.313 & 0.291 & 0.383 \\
\hline & 50 & 8.842 & 0.568 & 0.370 & 0.224 & ---- & 0.523 \\
\hline & 100 & 17.81 & 0.607 & 2.00 & ---- & ---- & ---- \\
\hline \multirow{4}{*}{$\frac{5}{3}$} & 10 & 1.683 & 0.917 & ----- & 0.568 & 1.028 & 0.929 \\
\hline & 20 & 3.451 & 1.918 & 0.370 & 0.441 & 0.853 & 1.370 \\
\hline & 50 & 8.692 & 2.124 & 0.370 & 0.726 & ----- & 1.320 \\
\hline & 100 & 17.634 & 1.825 & 2.00 & ---- & ----- & ---- \\
\hline \multirow{4}{*}{ 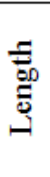 } & 10 & 2.402 & 1.116 & ----- & 1.183 & 2.852 & 5.880 \\
\hline & 20 & 3.580 & 2.099 & 3.132 & 1.475 & 3.513 & 3.267 \\
\hline & 50 & 8.139 & 2.615 & 2.907 & 1.864 & ---- & 3.405 \\
\hline & 100 & 16.755 & 6.051 & 2.161 & $-\cdots$ & ---- & ---- \\
\hline
\end{tabular}

\section{Chips rate dimension (CRD, \%)}

The average values of the chips size distribution can be seen in figure (18) for white and local woods. Increasing the Per1 to Per2 variables leads to an increase in chip size for both white and local woods.

The percentage of the size class $(>10 \mathrm{~mm}$ ) rises from 16.4 to $20.0 \%$ for chips thickness (Th) while the percentage of the size classes (50 and 100 $\mathrm{mm}$ ) decreases with great drum cutting revolutions. The variation in size distribution is linear with increasing cutting drum revolution, meaning that the greatest percentage of the class size $(>10)$ will be produced at Per2. 


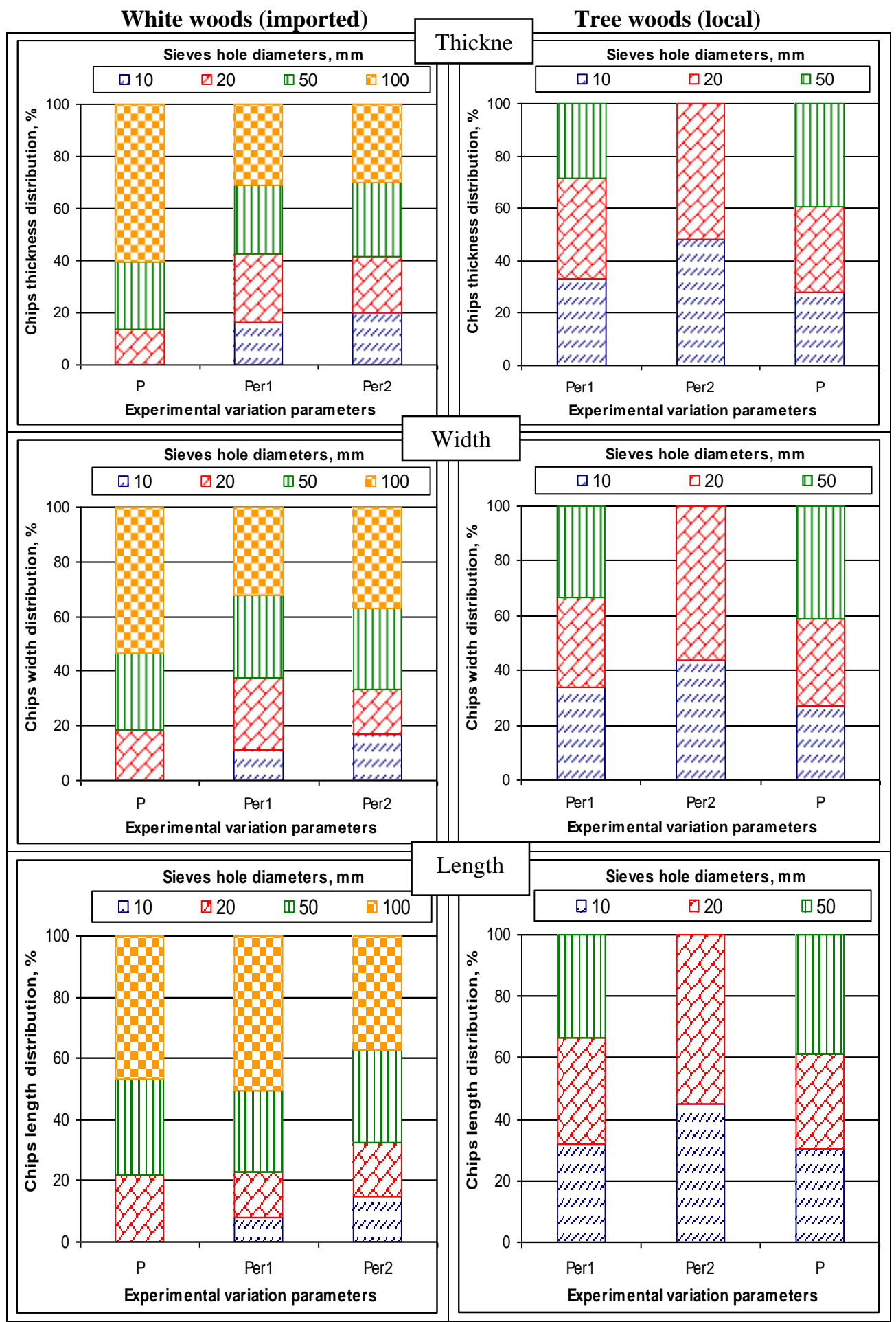

Figure (18): Chips rate dimension curves for wood chips variables 


\section{The chipper wood machine productivity}

The productivity of offset slide crank chipper wood machine (local model MUPM) was evaluated under two types of wood (local and white woods), different cutting depth and three levels of cutting drum revolution (rpm). Also, the wood moisture content for two woods types were nearly equal to $17 \%$ (exported wood) and blow or equal $33 \%$ (for local wood). The above functions were created as shown in figure (19).
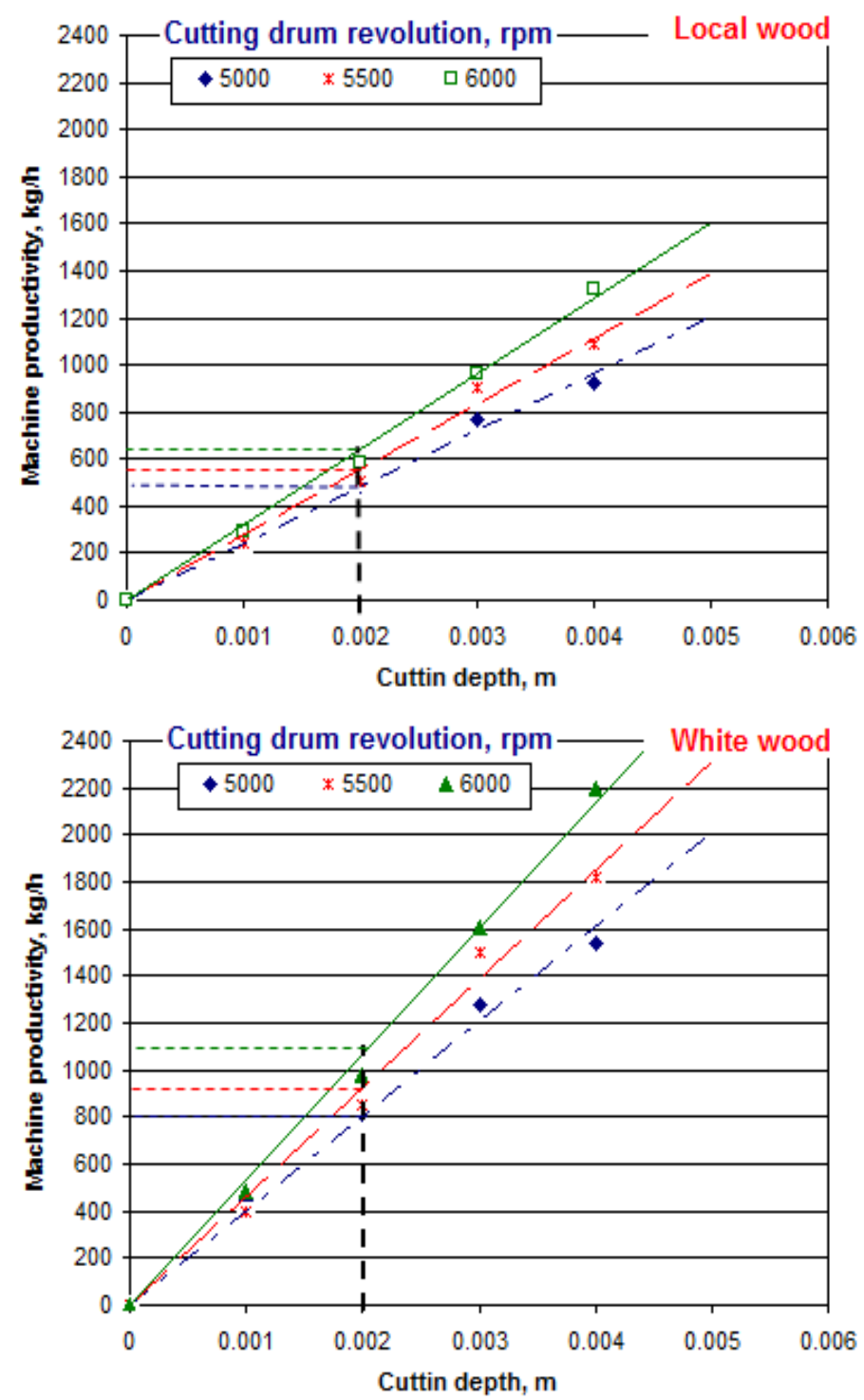

Figure (19): The wood chips productivity via cutting depth for two wood types 
Generally, increasing each of cutting depth and cutting drum revolution increasing the wood chips productivity. For example, at cutting depth of $2.0 \mathrm{~mm}$ and using the white woods, the chips production were 395.64; 435.2 and $474.76 \mathrm{~kg} / \mathrm{h}$ at 5000; 5500 and 6000 cutting drum revolution. The same trend was found at using local wood material. The wood chips productivity were $237.38 ; 261.12$ and $284.86 \mathrm{~kg} / \mathrm{h}$ at $5000 ; 5500$ and 6000rpm cutting drum revolution. From above results, the machine chips productivity vary depending on the type of wood, as well as different operating parameters such as cutting depth and drum revolution.

\section{REFERENCES}

Bergander, A. and Salmén, L. (2000). The transverse elastic modulus of the native wood fibre wall. Journal of Pulp and Paper Science: vol.26, No. 6: 234-238.

David, h. Myszka (2012). Machines and mechanisms applied kinematic analysis. Pearson education, inc., publishing as prentice hall, one lake street, upper saddle river, new jersey, 07458.

Gonçalves, R. and Néri A. C. (2005). Orthogonal cutting forces in juvenile and mature pines taeda wood, Sci. Agric. (Piracicaba, Braz.), 62(4), p. 310-318.

Ismail, Z. E. (2004). The first report of project (Developing the metering unite of the pneumatic planter) financed by Mansoura University researches unite.

Ismail, Z. E. (2009). Soil response to tillage treatments. Agricultural Mechanization in Asia, Africa and Latin America (AMA). Vol. 40, No. 4 autumn: 9-14.

Ismail, Z. E. and Abou Habaga, M. M. (2008). Theoretical approach to determine the share dimensions of uproot palm date. Misr. J. Ag. Eng., 25(3): 746-757.

Jernkvist, L. O. and Thuvander, F. (2001). Experimental determination of stiffness variation a cross growth rings in picea abies; Holzforschung Vol. 55, No. 3: 309-317. 
Kajberg, J. and Wikman, B. (2007). Viscoelastic parameter estimation by high strain-rate experiments and inverse modeling - Speckle measurements and high speed photography; International Journal of Solids and Structures 44: 145-164.

Kline, W. A.; DeVor R. E. and Lindberg J. R. (1982). The Prediction of cutting forces in end milling with application to cornering cuts. Int. J. Mach. Tool Des. Res., 22 (1), p. 7-22.

Sutherland, J.W. and DeVor, R. E. (1986). An improved method for cutting force and surface error prediction in flexible end milling systems. Journal of Engineering for Industry, 108, p. 269-279.

Svensson, B. A. (2007). Frictional studies and high strain rate testing of wood under refining conditions. Doctoral thesis, Mid Sweden University, Department of Natural science, Sundsvall.

Thuvander, F.; Sjödahl, M. and Berglund, L.A. (2000). Measurement of crack tip strain field in wood at scale of growth rings; Journal of Materials Science 35: 6267-6275.

Tlusty J. S. S., (1991). An overview of modeling and simulation of the milling process. Journal of Engineering for Industry, 1991, 113, p. 169-175.

Toenshoff, H. K. and Denkena, B. (2013). Basics of cutting and abrasive processes. Lecture Notes in Production Engineering, DOI: 10.1007/978-3-642-33257-9_2, Springer-Verlag Berlin Heidelberg.

Uhmeier, A. (1995). Some fundamental aspects of wood chipping; Tappi J Vol. 78, No. 10: 79-86.

Wen-Hsiang Lai, (2000). Modeling of cutting forces in end milling operations. Tamkang Journal of Science and Engineering, 2000, 3(1), p. 15-22.

Zmitrowicz, A. (2006). Models of kinematics dependent anisotropic and heterogeneous friction; International Journal of Solids and Structures, 43(14-15):4407-4451. 


\section{الملخص العربي \\ مواصفات إنتاج رقائق الخشب كنتيجة لوضع درفيل التقطيع

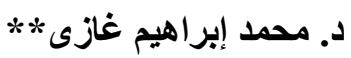

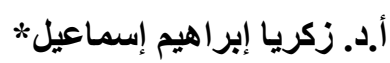

في الآونة الأخيرة انتشر في العالم العديد من معدات تجهيز مخلفات الأشجار الحقلية وتحوليها الي قطع صغيرة. ونظر اً لاتساع الأر اضى الزراعية في مصر وخاصة في الأر اضي الجديدة

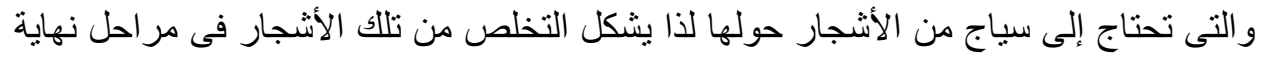

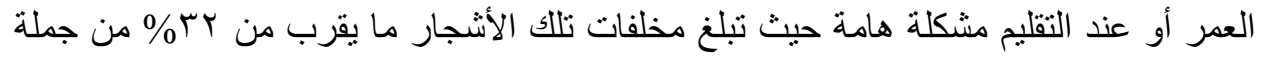

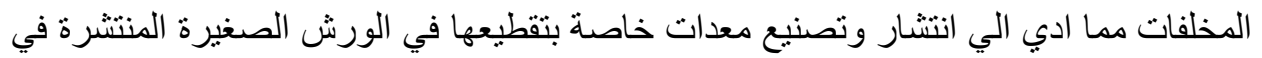

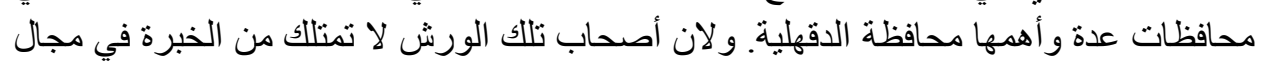

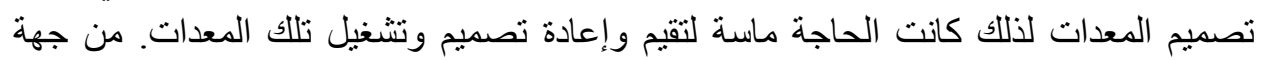
اخري ارتفع الطلب على استخدام نشارة الأشجار في كثير من الأغر اض مما دفع الورش الته الي تصنيع تلك المعدات بكثرة لإنتاج رقائق الخشب. لذلك يعتبر الهدف الأساسي لهذا البحث تقييم

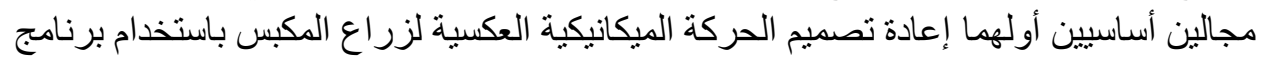

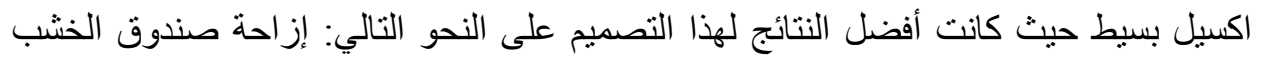

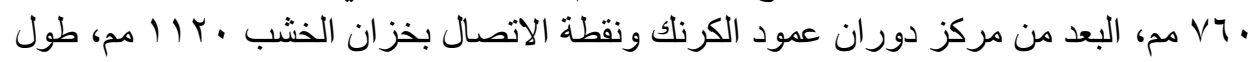

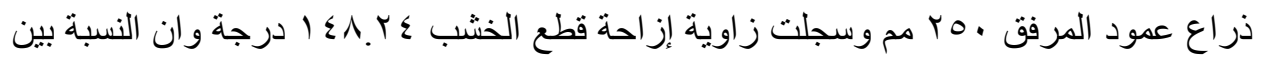

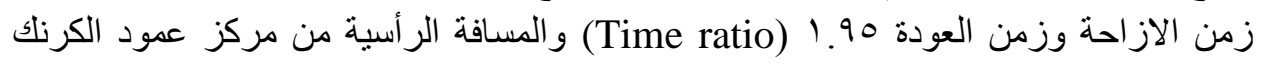

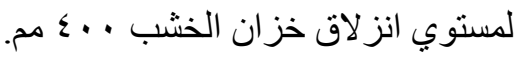
و التقييم الثاني يشمل در اسة خصائص رقائق الخشب المنتجة بو اسطة المعدة وذللك عن طريق قياس سمك رقائق الخشب (Chips Thickness ratio) و التقييم الحجمي للرقائق المنتجة وتقييم الإنتاجية.

* أستاذ تكنولوجيا القوى والآلات ـ قسم الهندسة الزراعية ـ كلية الزراعة ـ جاعة جامعة المنصورة - مصر.

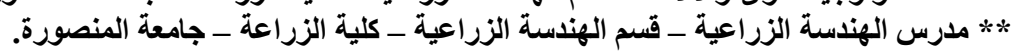

